\title{
Invandringsfrågan och möjligheter för invandringsfientliga partier att lyckas i Sverige
}

\section{Carl Dahlström \& Peter Esaiasson}

SAMMANDRAG: Invandringskritiska partier har haft varierande framgångar i västeuropeiska val. I den här artikeln prövar Carl Dahlström och Peter Esaiasson några vanliga förklaringar till varför invandringskritiska partier misslyckades i svenska val under lång tid. De använder flera typer av data för att undersöka den politiska dynamiken från 1970talet fram till valet 2006. (Riksdagsvalet 2010 kommenteras i slutsatserna.) Analysen visar att den långa raden av misslyckanden för invandringskritiska partier inte kan förklaras av låg efterfrågan på deras politik bland medborgarna. Däremot finns det starkt empiriskt stöd för partistrategiska förklaringar. Mer specifikt visar författarna att en avvisande sakfrågestrategi från de etablerade partierna har varit effektiv. Datamaterialet stödjer också antagandet att etablerade högerpartier är mer benägna än vänsterpartier att förorda en restriktivare invandringspolitik.

NYCKELORD: Sverigedemokraterna; invandringskritiska partier; riksdagsval; sakfrågestrategier; empirisk forskning.

pUbLICERINGSHISTORIK: Översättning av artikeln "The Immigration Issue and AntiImmigrant Party Success in Sweden 1970-2006. A Deviant Case Analysis" från tidskriften Party Politics, volym I9, nr 22013 (http://dx.doi.org/Io.II77/1354068811407600).

CARL DAHLSTRÖM är docent i statsvetenskap vid Göteborgs universitet.

PETER ESAIASSON är professor i statsvetenskap vid Göteborgs universitet.

FÖRSLAG PÅ KÄLLANGIVELSE:

Dahlström, Carl \& Peter Esaiasson (2013) "Invandringsfrågan och möjligheter för invandringsfientliga partier att lyckas i Sverige", i Det vita fältet II. Samtida forskning om högerextremism, specialnummer av Arkiv. Tidskrift för sambällsanalys, nr 2, s. 15-43. DoI: http://dx.doi.org/I0.13068/2000-6217.2.I

(C) original: SAGE Publications 2013

(C) svensk version: Författarna/Arkiv förlag \& tidskrift 2013

(publicerad I6 september 20I3)

Artikeln distribueras enligt en upphovsrättslicens från Creative Commons:

Erkännande-Ickekommersiell-IngaBearbetningar 3.o Unported, som medger fri ickekommersiell användning och spridning i oförändrat skick så länge källan anges. 
Arkiv. Tidskrift för samhällsanalys är en sakkunniggranskad vetenskaplig tidskrift för samhällsvetenskap och historia. Samtliga artiklar publiceras fritt tillgängliga på:

$$
\text { www.tidskriftenarkiv.se }
$$

(beständig länk, DoI: http://dx.doi.org/IO.I3068/2000-62I7)

Den här artikeln finns tillgänglig i följande format:

PDF \& HTML: via beständig länk, DOI: http://dx.doi.org/IO.I3068/2000-62I7.2.I EPUB: ingår i e-boksutgåva av numret, ISBN: 978 9I 7924254 I TRYCK: ingår i bokutgåva av numret, ISBN: 978 9I 79242558

Grafisk utformning och sidnumrering är identisk i pdf och tryck.

Samtliga artiklar i nr 2 (2013), Det vita fältet II. Samtida forskning om högerextremism, nås via beständig länk, DoI: http://dx.doi.org/I0.13068/2000-6217.2 redaktion för numret: Mats Deland, Paul Fuehrer och Fredrik Hertzberg

Arkiv. Tidskrift för sambällsanalys ISSN: 2000-62I7 (för elektronisk resurs) ISSN: 2000-6225 (för tryckta nummer)

ges ut av

Stiftelsen Arkiv för främjande och spridning av samhällsvetenskaplig och historisk forskning

genom

Arkiv förlag \& tidskrift

Box 1559 SE-22I OI Lund BESÖK: L Gråbrödersg 3 c, ipg TEL: O46-I3 3920

ARKIV FÖRLAG: arkiv@arkiv.nu·www.arkiv.nu TIDSKRIFTEN ARKIV: red@tidskriftenarkiv.se.www.tidskriftenarkiv.se

ANSVARIg UTGIVARE \& CHEFREDAKTÖR: Sven Hort AdMinistrativ Redaktör: David Lindberg ReDAKTörer: Paavo Bergman, Lisa Kings, Zhanna Kravchenko 


\section{Invandringsfrågan och möjligheter för invandringsfientliga partier att lyckas i Sverige}

\section{CARL DAHLSTRÖM \& PETER ESAIASSON}

\section{Inledning}

Invandringsfrågan blir allt viktigare i Västeuropa. I några länder - Österrike, Belgien, Danmark, Frankrike, Italien, Nederländerna - har partier som är motståndare till invandring kunnat använda frågan för att nå valframgångar. I andra länder har invandringsfientliga partier varit mindre framgångsrika. I den här artikeln analyserar vi varför skillnaderna är så stora.

Forskning på området har utvecklats snabbt under de senaste decennierna. I dag finns det en omfattande litteratur med teorier kring, bland annat, konstitutionella arrangemang (t.ex. Swank \& Betz 2003; Norris 2005), efterfrågan av en politik som minskar invandringen (t.ex. Betz I994), utbudet av partier som erbjuder en politik för att minska invandringen (t.ex. Ivarsflaten 2005) och de etablerade partiernas sakfrågestrategier (t.ex. Arzheimer \& Carter 2006; Arzheimer 2009; Meguid 2005; 2008).

Medan teoriutvecklingen varit snabb begränsas möjligheterna till empiriska prövningar av att dataunderlaget är så litet. Visserligen har

Den här artikeln publicerades ursprungligen på engelska som "The Immigration Issue and Anti-Immigrant Party Success in Sweden 1970-2006. A Deviant Case Analysis" i tidskriften Party Politics, volym I9, nr 2 2013 (http://dx.doi.org/IO.II77/I3540688II407600). Tack till förlaget Sage som tillåtit denna publicering på svenska. 
några forskare lyckats skapa länderjämförbara data (t.ex. Arzheimer 2009; Meguid 2005; Ivarsflaten 2005; Brug, Fennema \& Tillie 2005), men med tanke på det lilla antalet inblandade länder och det stora antalet tänkbara förklaringar finns det all anledning att leta efter fler relevanta dataobservationer (King, Keohane \& Verba 1994). Den här artikeln hävdar att teoretiskt informerade fallstudier är en möjlig väg framåt (t.ex. George $\&$ Bennett 2004).

Mer precist fokuserar artikeln på ett avvikande fall där invandringsfientliga partier misslyckats under lång tid, nämligen Sverige. Tre faktorer gör den långa perioden av misslyckanden särskilt intressant: För det första tillhör Sverige de länder som påverkats allra mest av internationell migration. Fram till I960-talet var Sverige etniskt homogent. I dag är tolv procent av befolkningen född utomlands, och därmed är Sverige ett av de mest etniskt heterogena länderna i Europa (OECD 2003; Coleman 2006). För det andra hade grannländerna Norge och Danmark stora och konkurrenskraftiga invandringsfientliga partier långt tidigare än Sverige, trots ett mindre inflöde av invandrare (se t.ex. Green-Pedersen \& Krogstrup 2008). För det tredje är de konstitutionella arrangemangen gynnsamma för nischpartier som konkurrerar genom att introducera nya frågor, vilket illustreras av Miljöpartiets framväxt som ett inflytelserikt grönt parti (se Meguid 2008 för en diskussion av nischpartier).

I riksdagsvalet 2010 lyckades som bekant Sverigedemokraterna att utnyttja denna gynnsamma kontext för att ta plats i riksdagen. Vi återkommer till detta val i sammanfattningen, men artikeln fokuserar på den långa raden av misslyckade försök från invandringsfientliga partier dessförinnan.

Till vårt förfogande har vi unika data som tillåter oss att studera den politiska dynamiken under perioden 1970-2006. Vi tycker oss hitta tre viktiga resultat. För det första hittar vi inget stöd för de teorier som lyfter fram medborgarnas krav på en politik som minskar invandringen. Trots att den allmänna opinionen i Sverige vanligtvis beskrivs som tolerant mot andra etniska grupper (Sides \& Citrin 2007; Hjerm 2007) visar resultaten tydligt att opinionen har varit tillräckligt invandringskritisk för att ett framgångsrikt invandringsfientligt parti skulle ha kunnat uppstå. För det andra finner vi stöd för de teorier som betonar vikten av partiernas stra- 
tegiska agerande i sakfrågor. I överensstämmelse med några viktiga teorier har de etablerade partierna systematiskt undvikit att använda invandringsfrågan i konkurrensen om rösterna. För det tredje bekräftar våra data att etablerade högerpartier är mer benägna att anamma en invandringskritisk politik än etablerade vänsterpartier.

Artikeln är upplagd på följande sätt: Först gör vi en mer utförlig presentation av de mest relevanta teorierna på området och diskuterar då även vår undersöknings design. Därefter gör vi en kort genomgång av svenska invandringsfientliga partier. Därpå följer den empiriska analysen av medborgarnas efterfrågan på invandringsfientlig politik samt av partiernas strategiska sakfrågeval under valrörelserna. Sedan uppmärksammar vi två kritiska perioder där historien kunde ha tagit en annan och för invandringsfientliga partier mer framgångsrik vändning. Slutligen summerar vi resultaten och diskuterar deras implikationer.

\section{Invandringsfrågan och valframgångar för invandringsfientliga partier}

Det finns ingen allmänt accepterad terminologi för den partifamilj vars valframgångar motiverar denna studie. Ibland refererar man till dessa partier som högerextrema (Carter 2005; Mudde 1996), radikala högerpartier (Norris 2005), radikala högerpopulistiska partier (Rydgren 20I0) eller populistiska högerradikala partier (Mudde 2007). Vi följer emellertid Brug, Fennema och Tillie (2005, s. 537) och använder deras term "invandringsfientliga partier" (anti-immigrant parties, se också Fennema 1997). Ett annat viktigt begrepp, "invandringsfrågan", definierar vi brett så att den innefattar både "reglering av invandringsströmmar och uppehållstillstånd" och "invandrarpolitik" (Hammar 1985, s. 7).

Forskning om framgångarna för invandringsfientliga partier lyfter fram fyra slags förklaringar (för aktuella översikter, se Rydgren 20ıo; Brug \& Fennema 2007). Den första typen av förklaringar berör konstitutionella arrangemang som valsystem och parlamentariska spärrar (Jackman \& Volpert 1996; Norris 2005; Swank \& Betz 2003). Den grundläggande idén är att invandringsfientliga partier lyckas bäst i proportionella valsystem och i system med låga spärrar. Kanske något överraskande är det 
empiriska stödet för detta påstående varierande. Medan en del studier hittar stöd för teorin (Jackman \& Volpert 1996; Norris 2005; Swank \& Betz 2003), visar andra att valsystemet inte har betydelse på det sätt som teorin förutsäger (Brug, Fennema \& Tillie 2005; Carter 2002; Mudde 2007, s. 233-237).

Det svenska fallet illustrerar den begränsade förklaringskraften hos teorier om konstitutionella arrangemang. Sveriges valsystem är strikt proportionellt och fyraprocentsspärren är förhållandevis låg i ett europeiskt perspektiv (Särlvik 2002). Dessutom har andra nya partier, i första hand Miljöpartiet, vunnit plats i riksdagen under perioden. Konstitutionella faktorer kan inte heller förklara långsiktiga förändringar i stödet för nya partier, eftersom det är ovanligt att valsystem ändras. I resten av vår analys kommer de konstitutionella faktorerna att hållas konstanta på en nivå som är gynnsamma för invandringsfientliga partier.

Utbudsteorier, den andra gruppen av potentiellt intressanta förklaringar, betonar betydelsen av de invandringsfientliga partiernas ideologiska ursprung och historia (Ignazie 1992; Kitschelt 1995; Carter 2002; Ivarsflaten 2006; jfr Brug, Fennema \& Tillie 2005). Argumentet är att partier som härstammar från fascistiska eller nynazistiska organisationer har sämre förutsättningar att lyckas än nya partier utan sådant historiskt bagage. Den viktigaste orsaken till detta är att partier med ursprung inom extremhögern måste komma över en barriär av dåligt anseende för att få röster (Ivarsflaten 2006). Vi betraktar helt klart teorierna om historiskt bagage som intressanta men i detta sammanhang har de ett begränsat förklaringsvärde. Eftersom teorierna är statiska till sin karaktär (ett partis ursprung förändras endast långsamt) kan de svårligen förklara enskilda invandringsfientliga partiers tillväxt. I den här studien kommer vi därför att notera det historiska arvet hos de svenska invandringsfientliga partierna, men prioritera mer dynamiska teorier.

En tredje grupp förklaringar tar sin utgångspunkt i medborgarnas efterfrågan av invandringsfientlig politik. Inom det här fältet finns sofistikerade teorier som riktar uppmärksamheten mot moderniseringens förlorare (Betz 1994), mot massarbetslöshet (Lubbers, Gijsberts \& Scheepers 2002; Arzheimer 2009), främlingsfientliga attityder (Knigge 1998) och nivån på invandringen (Golder 2003). Argumentet är att olika sorters 
hot skapar en efterfrågan på invandringsfientlig politik. I den här artikeln är det mindre viktigt exakt varför individer stöder en invandringsfientlig politik. Eftersom medborgarnas avfärdande av deras idéer är den självklara utgångspunkten när det gäller att förklara invandringsfientliga partiers misslyckande är ambitionen här bara att undersöka om det, trots partiernas misslyckande, faktiskt har funnits en substantiell efterfrågan för invandringsfientlig politik i Sverige.

I europeiska jämförelser brukar forskare betrakta den svenska opinionen som tolerant mot andra grupper och som positiv till en generös invandringspolitik (Sides \& Citrin 2007; Hjerm 2007). Relativa jämförelser säger emellertid inte att efterfrågan är låg också i absoluta termer. Efter en översikt av litteraturen drar Mudde (2007, s. 222) slutsatsen att "nativism" och andra populistiska högerradikala attityder är vitt spridda över Europa. För att påpeka det uppenbara behöver dessutom invandringsfientliga partier bara begränsat väljarstöd för att få representation i riksdagen.

Den färde typen av förklaringar fokuserar på de etablerade partiernas sakfrågestrategier. Sakfrågestrategier är viktiga eftersom de påverkar både vem som äger invandringsfrågan, och vilken betydelse den får (Arzheimer 2009; Arzheimer \& Carter 2006; Bale 2003; Green-Pedersen \& Krogstrup 2008; Meguid 2005; 2008). Det är framför allt två konkurrerande hypoteser från dessa teorier som är intressanta för oss. Enligt den första hypotesen kan etablerade partier hindra invandringsfientliga partier genom att närma sig deras politiska sfär och ta över invandringsfrågan (Brug, Fennema \& Tillie 2005). Enligt den andra hypotesen bör etablerade partier i stället lägga mindre vikt vid invandringsfrågan, eftersom invandringsfientliga partier kommer att vinna röster på att en stor del av den allmänna debatten handlar om deras huvudfråga (Arzheimer 2009; Arzheimer \& Carter 2006, s. 439; Bale 2003, s. 67). Det finns empiriska studier som stöder båda hypoteserna, men de har nästan aldrig testats samtidigt i en och samma studie.

Ytterligare insikter erbjuds av vad man kan kalla "nischpartiteorin", som handlar om hur nya partier når framgång genom att politiserar nya frågor. Invandring och miljöfrågor är två exempel på frågor som förs fram av nischpartier. Bonnie Meguid (2005; 2008), den ledande teoretikern 
på området, menar att etablerade partier generellt sett använder tre sakfrågestrategier för att försöka bemöta dessa partier: avvisningsstrategin (att undvika sakfrågan, vilket förväntas minska stödet för nischpartiet); anpassningsstrategin (att röra sig närmare nischpartiets position i sakfrågan, vilket också förväntas minska stödet för nischpartiet); och konfrontationsstrategin (att ta avstånd från nischpartiets position i sakfrågan, vilket förväntas öka stödet för nischpartiet). Eftersom distinktionen mellan anpassningsstrategin och konfrontationsstrategin identifierar två olika vägar för de etablerade partierna att ta upp invandringsfrågan tillför teorin viktig komplexitet till området.

Om vi slutligen riktar uppmärksamheten mot de etablerade partiernas motiv, så hävdar Bale (2003; 2008) att högerpartier allmänt sett har mest att vinna på att flytta sin agenda närmare de invandringsfientliga partiernas agenda. Han anger två skäl till detta. För det första äger högerpartier traditionellt frågor som ofta betonas av invandringsfientliga partier, såsom skärpningar av reglerna för invandringen, hårdare tag inom kriminalpolitiken och mot fusk inom välfärdssystemen (Bale 2008, s. 320). För det andra har högerpartier ett strategiskt intresse av att avlägsna "vad som i grund och botten är en konstlad begränsning av varje högerblocks storlek i ett parlament" (Bale 2003, s. 69).

\section{Undersökningsdesign och data}

I länderjämförande forskning används fallstudier ofta i illustrerande syfte. Här är dock ambitionen en annan. Studien kommer att undersöka stödet för konkurrerande teorier i ett nationellt sammanhang. Vi använder teorierna som beskrivits ovan för att identifiera vilka aspekter av utvecklingen som är viktiga och jämför vad som egentligen hände med de prediktioner som kan härledas från respektive teori. I metodlitteraturen är det välkänt att fallstudier inte kan utgöra någon avgörande kritisk prövning av teorier (t.ex. Lieberson I99I). Även om vi tar hänsyn till dessa begränsningar ger emellertid vår studie ett relevant bidrag till mer traditionellt jämförande design.

Vi har härlett tre empiriska frågor ur litteraturen: I. Är medborgarnas efterfrågan av invandringsfientlig politik tillräcklig för ett starkt invand- 
ringsfientligt parti? 2. Har etablerade partier strävat efter att tona ner betydelsen av invandringsfrågan i valdebatterna? Och, om invandring varit en betydelsefull sakfråga, har partiernas sakfrågestrategier varit huvudsakligen konfrontativa eller anpassningsorienterade? 3. Är Moderaterna, som det största etablerade partiet inom den politiska högern, mer frestade att introducera en kraftigt invandringsbegränsande politik i valdebatterna än Socialdemokraterna och andra partier till vänster?

För att mäta medborgarnas efterfrågan av invandringsfientlig politik förlitar vi oss på data från SOM-undersökningarna, de årliga surveyundersökningar som genomförs vid Göteborgs universitet. Undersökningarna är av hög kvalitet och omfattar ett representativt urval av vuxna och ungdomar som bor permanent i Sverige (Holmberg \& Weibull 2009; se vidare SOM-institutets hemisda http://www.som.gu.se). Vi använder också surveydata från Svenska valforskningsprogrammet om riksdagsledamöter och väljare (Holmberg 1994; se vidare programmets hemsida http://www.valforskning.pol.gu.se). ${ }^{\text {I }}$ För att fånga de etablerade partiernas sakfrågestrategier studerar vi i första hand vilka frågor partierna tagit upp under valkampanjerna. Här förlitar vi oss på primärdata från POPstudien, som är en detaljerad kvantitativ innehållsanalys av valmanifest och tevedebatter (Esaiasson \& Håkansson 2009).

\section{Utbudet av invandringsfientliga partier i Sverige}

Trots att Sverige under lång tid inte hade något invandringsfientligt parti på nationell nivå, har det funnits partier som fört fram invandringskritisk politik på lokal nivå under några decennier. I mitten av I980-talet vann Skånepartiet mandat i några kommuner i Skåne. Efter en omtalad omröstning om mottagandet av flyktingar i deras kommun kunde ett annat öppet främlingsfientligt parti, Sjöbopartiet, få ytterligare representation i kommunerna i Skåne. I enlighet med utbudsteorierna var båda

I. Svarsfrekvensen för riksdagsundersökningarna, som har genomförts regelbundet sedan 1985, är över 90 procent bland de 349 ledamöterna. Forskningsledare är Sören Holmberg (I985-20I0), Peter Esaiasson (1985-1994) och Martin Brothén (I994-2006). Detaljerade beskrivningar finns i Brothén och Holmberg (2003) och Brothén, Holmberg och Eriksson (2007). 
dessa regionalt framgångsrika partier nybildade utan besvärande kopplingar till ett ideologiskt extremt ursprung (Integrationsverket 2006; Rydgren 2002; Widfeldt 2004).

Tabell I visar valresultat för de båda hittills mest framgångsrika invandringsfientliga partierna på nationell nivå: $\mathrm{Ny}$ demokrati och Sverigedemokraterna. Ny demokrati skapades strax innan valet 199I. Partiet lyckades få 6,7 procent av rösterna på nationell nivå och fick 25 riksdagsplatser. Emellertid föll stödet till I,2 procent redan i det följande valet, och partiet upplöstes kort därefter.

Tabell I. Ny demokratis och Sverigedemokraternas resultat vid riksdagsvalen $1988-2006$ i procent

\begin{tabular}{lccccccc} 
& I988 & I991 & I994 & 1998 & 2002 & 2006 & 2010 \\
\hline Ny demokrati & - & 6,7 & I,2 & 0,2 & - & - & - \\
Sverigedemokraterna $^{*}$ & 0,0 & 0,I & 0,2 & 0,4 & I,4 & 2,9 & 5,7 \\
\hline
\end{tabular}

Anmärkning: Sverigedemokraterna grundades 1988 och Ny demokrati I99I.

* Valresultaten 1988, I99I och 1994 är ungefärliga, baserade på Sverigedemokraternas egna uppgifter.

Källor: SCB och Valmyndigheten.

För närvarande är förstås Sverigedemokraterna störst. Partiet skapades I988 ur den nationalistiska och främlingsfientliga organisationen Bevara Sverige svenskt (Rydgren 2004). Även om partiet var långt under spärren på fyra procent, tredubblade det sitt stöd på nationell nivå i valet 2002 och dubblade det igen i valet 2006. På den lokala nivån har partiet snabbt ökat sitt stöd; efter valet 2006 fick det representation i I 40 av 290 kommuner (en ökning från 29 kommuner år 2002 och 5 år 1998). Under valkampanjen 20 Io fick Sverigedemokraterna mycket uppmärksamhet i den offentliga debatten och politiska experter förväntade att de skulle ta sig in i riksdagen. Som förutsett gick de också framåt och fick stöd från 5,7 procent av väljarna och tog sig därmed över spärren till riksdagen. De vann också ytterligare platser i kommunerna och är sedan valet år 2010 representerade i 245 kommuner av 290.

Den snabba framgången för $\mathrm{Ny}$ demokrati jämfört med Sverigedemokraterna stämmer överens med vad utbudsteorier säger om betydelsen av 
de invandringsfientliga partiernas bakgrund (se t.ex. Ivarsflaten 2006). Emellertid hade Ny demokrati, som vi ska visa nedan, till en början en mer varierad politisk agenda än Sverigedemokraterna, som länge nästan uteslutande ägnade sig åt invandringskritik. Dessutom kan utbudsteorier inte ensamma förklara att Ny demokrati försvann så snabbt eller att stödet ökat för Sverigedemokraterna. Även om vi anser att utbudsteorier kan ge en del av förklaringen, riktar vi vår uppmärksamhet mot teorier som har möjlighet att förklara den dynamiska utvecklingen av de invandringsfientliga partiernas attraktivitet.

\section{Medborgarnas efterfrågan på invandringsfientlig politik}

Kan den långa perioden av misslyckanden för invandringsfientlig politik bero på att medborgarnas efterfrågan varit låg? Eftersom nivåskattningar av medborgarnas attityder är förknippade med metodproblem kommer vi att titta på olika indikatorer och använda olika referenspunkter.

Vi utgår från medborgarnas stöd för ett politiskt förslag om att "ta emot färre flyktingar i Sverige", som funnits med i SOM-undersökningarna under lång tid. Kärnan i invandringsfientliga partiers program är att begränsa invandringen. Att ändra invandringspolitiken i restriktiv riktning är därmed en viktig del av den ambitionen. Vi betraktar svar på den enkätfrågan som en indikator på efterfrågan av invandringsfientlig politik.

Under perioden mellan åren 1990 till 2006 har andelen respondenter som stöder en mer restriktiv invandringspolitik aldrig understigit 43 procent, som högst har den varit 65 procent (Demker 2009, s. 49). Dessutom kan stöd för en restriktiv politik inte avskrivas som en effekt av hur frågan har ställts eller hur svarsalternativen har utformats. Vid en omvänd formulering av det politiska förslaget, där ett instämmande svar indikerar stöd för en generös invandringspolitik, är det bara omkring 20 procent av de svarande som uttrycker stöd för en mer liberal politik (Demker 2009, s. 49).

Resultaten från riksdagsundersökningarna är en annan referenspunkt. Som man kan se i asterisknoten till figur I (nedan) är den högsta andelen riksdagsledamöter som stöder en mer restriktiv politik 17 procent (år I994), och stödet bland ledamöterna ligger vanligen under Io procent. 
Mätt med en och samma intervjufråga tycker medborgarna uppenbarligen att restriktiv invandringspolitik är mer attraktiv än vad deras valda representanter gör. ${ }^{2}$

Har invandringsfrågan en särskild karaktär? Forskning om politisk lyhördhet visar att valda ledamöter oftast är ganska känsliga för väljarnas politiska önskemål (se Lax \& Phillips 2009 och den litteratur som refereras där). Åtminstone när det gäller centrala politiska frågor är det ovanligt att valda representanter inte anpassar sina åsikter efter medborgarnas. Om representanterna inte gör den anpassningen indikerar det att medborgarnas efterfrågan av invandringsfientlig politik inte helt har tillfredsställts.

Som ett mått på lyhördheten i förhållande till medborgarnas attityder visar figur I skillnaden i procentenheter mellan riksdagsledamöternas och medborgarnas stöd för ett förslag om att "ta emot färre flyktingar i landet" vid riksdagsvalen 1994-2006. Höga tal indikerar en stor skillnad mellan politikerna och den allmänna opinionen vid ett enskilt tillfälle, och utvecklingen över tid avspeglar lyhördheten. Som referenspunkt inkluderar vi motsvarande information om politiska förslag som gäller miljön ("förbud mot bilar i innerstaden") och den dominerande höger-vänsterdimensionen ("minska storleken på den offentliga sektorn").

Resultaten indikerar att invandringsfrågan verkligen är speciell. Nivån på den bristande överensstämmelsen mellan riksdagsledamöterna och väljarna är genomgående tre till fyra gånger högre än när det handlar om miljöskydd och vänster-höger-politik. Dessutom är den bristande överensstämmelsen mycket större än för något annat politiskt förslag som ingår i undersökningarna 1994, 1998 och 2002, och näst störst för $2006 .^{3}$

Sist i det här avsnittet undersöker vi om medborgarna visserligen efterfrågar en mer invandringsfientlig politik men ger den låg prioritet jämfört

2. Resultaten för varje parti presenteras i tabell 4 nedan (s. 35 ), och diskuteras i ett påföljande avsnitt.

3. Den största oenigheten 2006 handlade om ett förslag om att låta Turkiet inträda $\mathrm{i}$ EU, vilket också speglar invandringsfrågan. Antalet identiskt formulerade politiska förslag som inkluderas i Svenska valforskningsprogrammets studier varierar en aning under åren: 20 förslag år 1994; I2 år 1998; 17 år 2002; I9 år 2006. 8 förslag har inkluderats i alla fyra studierna. 
Figur I. Nivå på politisk oenighet mellan riksdagsledamöter och vuxna medborgare 1994-2006

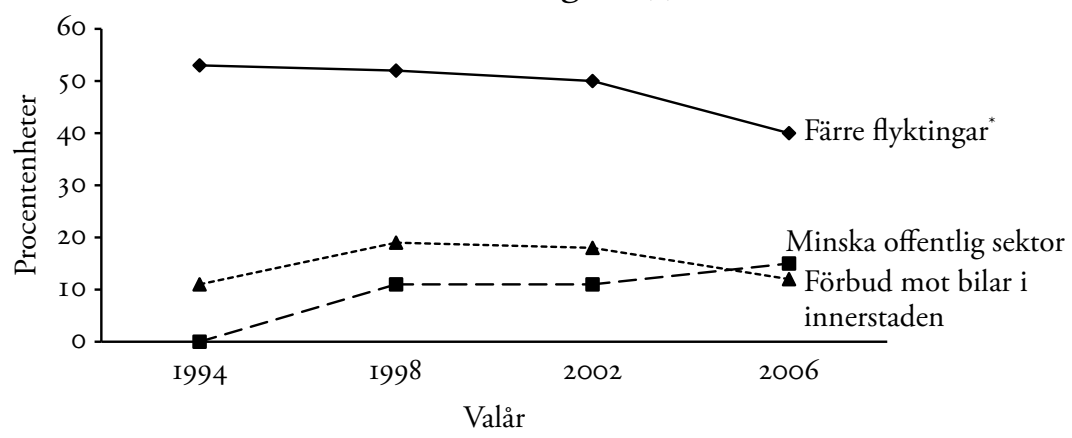

Anmärkning: Skillnaden i procentandelar mellan riksdagsledamöter och vuxna medborgare angående förslag (väldigt eller ganska bra).

* Riksdagsledamöter/medborgare som stöder förslaget i procent: I7/70 (I994), 9/6I (1998), 7/57 (2002), 8/48 (2006).

Källa: Holmberg (1996; 2002; 2004; 2010).

med andra frågor. Om medborgarna anser att invandringsfrågan är lågt prioriterad, kan efterfrågan på invandringsfientlig politik vara otillräckligt för att invandringsfientliga partier ska ha framgång. ${ }^{4}$

Som mått på hur viktig sakfrågan är, använder vi en öppen fråga om "det viktigaste problem som landet står inför i dag" från SOM-undersökningarna 1987-2006. Vi vet från tidigare forskning, till exempel undersökningar om relationen mellan opinion och policy när det gäller frågan om gränskontroll och asyl i Storbritannien (Jennings 2009), att de flesta individer som ser invandring som ett stort problem vill ha en restriktiv invandringspolitik. Enligt SOM-undersökningarna stödde mellan 60 och 80 procent av de svarande som såg "invandring" som ett viktigt problem

4. En komplicerande faktor är att sakfrågans betydelse beror på vilka strategier partierna har för att bygga sina agendor (t.ex. Zaller 1992). Eftersom en sakfråga kan göras viktig om den förs fram av de etablerade partierna, betyder den låga vikten hos invandringsfrågan inte att den saknar potential att locka väljare. De etablerade partiernas sakfrågestrategier diskuteras i följande avsnitt. 
för landet också förslaget att minska flyktinginvandringen. Figur 2 visar andelen svarande som identifierar "invandring" som ett viktigt problem för varje år. Som referenspunkt inkluderar vi motsvarande information om "miljöfrågan" och om den sakfråga som nämns av de flesta av de svarande ("huvudfrågan"). Vi inkluderar också information om den årliga rankningen av "invandring" på en lista av I7 frågor och problem. ${ }^{5}$

Resultaten indikerar att "invandring" är något som bekymrar medborgarna. Varje år identifierar mellan sju och tjugofem procent av de svarande "invandring" som ett av de viktigaste problem som Sverige står inför. Enligt rankningen hamnar "invandring" hela tiden bland landets viktigaste problem. Det är inte medborgarnas främsta bekymmer - inte något år identifieras "invandring" som landets främsta problem - men från mitten av 1990-talet har det varit jämförelsevis viktigare än "miljön".

Medan frågan är relativt viktig under de flesta av dessa år, framstår det tidiga 1990-talet som en exceptionell period. Under två år efter varandra, I992 och I993, hörde "invandring" till de tre viktigaste problemen. Detta var år när Sverige tog emot ett ovanligt stort inflöde av flyktingar från det krigshärjade före detta Jugoslavien (Dahlström 2004, s. 50-55), och även upplevde våldsamma aktioner mot flyktingförläggningar och enskilda invandrare (Lodenius \& Larsson 1994). Landet drabbades samtidigt av en ekonomisk recession som motiverade drastiska nedskärningar i välfärdssystemen (Anderson 200I; Lindvall 2004). Med början vid valåret 1994 minskade betydelsen till en lägre nivå (om än högre än innan krisåren). Vi kommer att titta mer på den här kritiska perioden i ett senare avsnitt.

Vår övergripande slutsats är att den svenska opinionen om invandring skiljer sig åt i grad men inte i art från andra västeuropeiska länder. Det verkar orimligt att hävda att låg efterfrågan av deras politik kan förklara den långa följden av misslyckanden för invandringsfientliga partier i Sverige.

5. Följande frågor och problem registrerades i SOM-undersökningarna: hälsovård, sysselsättning, miljön, utbildningen, ekonomin, pensioner och äldrevård, lag och ordning, socialförsäkringar, skatter, familjepolitik, transporter, moraliska frågor, energipolitik, privatiseringar av offentlig sektor, jordbruk, Europeiska unionen. Upp till tre frågor registrerades för varje respondent. 
Figur 2. De viktigaste problem som landet står inför, 1987-2006

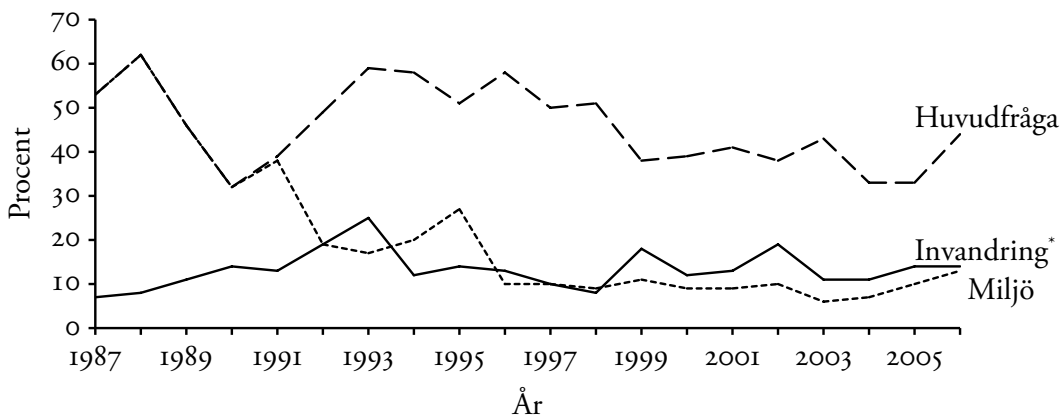

Anmärkning: Andel i procent av respondenter som nämner invandringen och miljön som de viktigaste frågorna för Sverige i dag. Miljön och huvudfrågan finns med för jämförelsens skull. Från 1987 till 1990 var miljön den främsta sakfrågan.

* Rankning för varje år: 8, 9, 7, 4, 7, 3, 3, 6, 6, 5, 6, 9, 6, 6, 5, 4, 6, 6, 6 och 5 av I7.

Källa: Holmberg och Weibull (2009, s. I2-13).

\section{Etablerade partiers sakfrågestrategier}

I det här avsnittet ska vi undersöka de etablerade partiernas prioritering av invandringsfrågan under valkampanjerna. Enligt Meguids (2005; 2008) terminologi indikerar en svag betoning av sakfrågan att partierna valt en avvisande sakfrågestrategi. Stark betoning kan indikera anpassning till invandringsfientliga partier lika väl som konfrontation. För att skilja mellan de senare strategierna, undersöker vi vilka politiska positioner som intas.

Figur 3 (nedan) visar andelen budskap som ägnas åt invandring i valmanifesten 1970-2006. Åter används miljöfrågan och den sakfråga som vid varje tillfälle får mest uppmärksamhet som referenspunkter. Tabell 3 (nedan, s. 33) ger detaljerad information om de individuella partierna.

Som framgår av figur 3 och tabell 3 är det i regel bara en liten andel av budskapen som handlar om invandringspolitik (mellan noll och fyra procent). Man kan jämföra med miljöfrågan, som varierar från två till tio procent. Det är viktigt att notera att vid valet 1988, när Miljöpartiet för 
Figur 3. Politiska frågor i valmanifest, 1970-2006

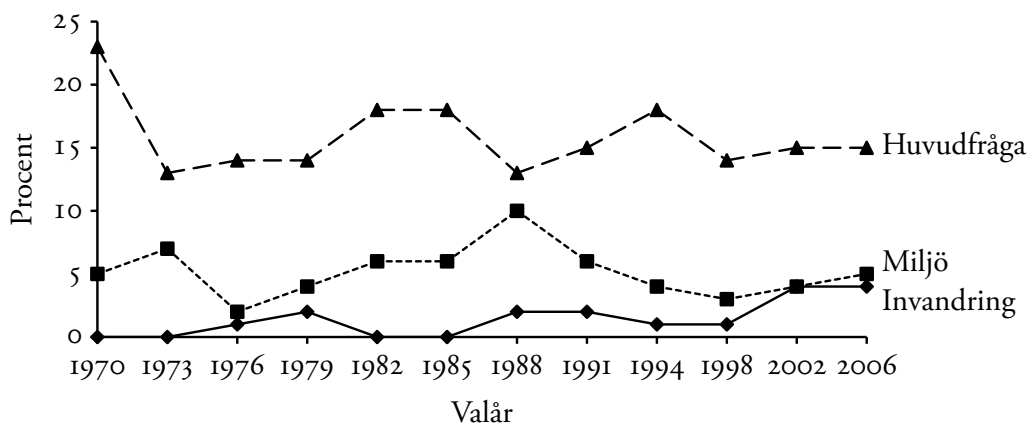

Anmärkning: Andel i procent av valmanifest som ägnas åt invandringsfrågor. Miljön och huvudfrågan finns med för jämförelsens skull.

Källa: Esaiasson och Håkansson (2009).

första gången tog sig in i riksdagen, låg deras favoritfråga högt på agendan för de etablerade partierna (i ett försök att anpassa sig, uttryckte de etablerade partierna ett starkt stöd för miljöskydd). Resultaten verkar helt klart stödja uppfattningen att de etablerade partierna använt en avvisande sakfrågestrategi mot invandringsfientliga partier.

Valmanifesten innehåller budskap som formuleras före valkampanjerna. För att fånga hur sakfrågestrategierna utvecklas under kampanjen visar figur 4 (och tabell 3 nedan) vilken andel av budskapen som ägnas åt invandringen i SVT:s avslutande partiledardebatt två dagar innan valdagen 1970-2006 (se vidare t.ex. Esaiasson 1992).

Även nu är huvudmönstret att de etablerade partierna ägnat lite uppmärksamhet åt invandringsfrågan och därmed valt en avvisande sakfrågestrategi. Under huvuddelen av de undersökta åren har andelen budskap som ägnats åt invandringen varierat mellan noll och en procent när kampanjen nått in i sitt mest intensiva stadium. Med början vid valet 1985 har till exempel miljöfrågor spelat större roll i partiernas valbudskap. Det finns emellertid två undantag från det allmänna mönstret att inte tala om invandringen i de tevesända debatterna och det är valen 1994 och 2002. Vi återvänder strax till dessa val. 
Figur 4. Politiska frågor i tevesända partiledardebatter, I970-2006

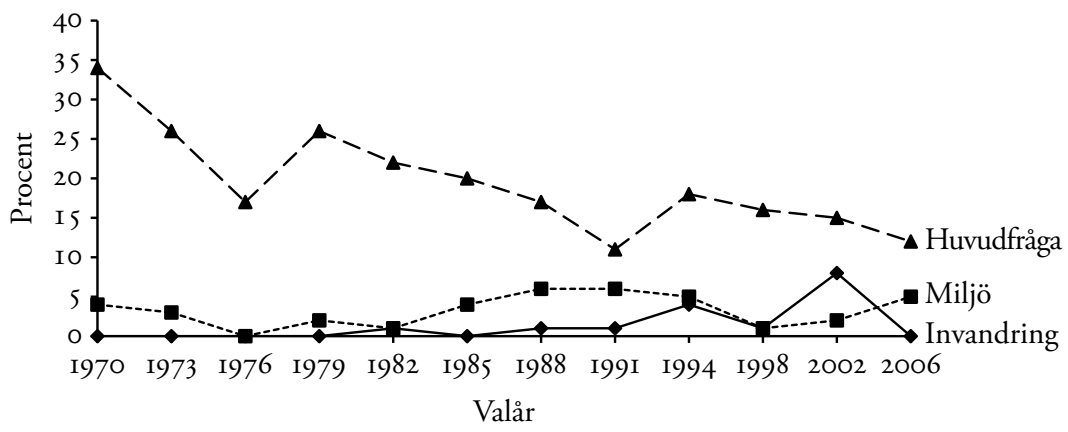

Anmärkning: Andel i procent av debattiden som ägnas åt invandringsfrågan. Miljön och huvudfrågan finns med för jämförelsens skull.

Källa: Esaiasson och Håkansson (2009).

Medan innehållsanalys av manifest och tevesända debatter är viktiga, finns det två begränsningar för dessa indikatorer. För det första kan partier kommunicera med väljare även genom andra forum (Naurin 2009). För det andra täcker vår analys enbart tydligt uttryckta budskap. Det senare är problematiskt eftersom det är väl känt att partier ibland använder implicita sätt att kommunicera sina uppfattningar (Gilens 1999; Federico 2004).

För att få en mer komplett bild av invandringsfrågans ställning i valkampanjerna använder vi oss av väljarnas uppfattningar om partiernas kampanjfrågor såsom de fångas av en öppen fråga i de svenska väljarundersökningarna. Mer specifikt har de svarande ombetts att ange vilka frågor varje parti har betonat mest under kampanjen (Oscarsson \& Holmberg 2008, s. 52). Figur 5 (nedan) visar den högsta andel av svarande som uppfattade att invandringen var den viktigaste sakfrågan för vart och ett av de etablerade partierna (se också tabell 3). Liksom tidigare används miljöfrågan och valets viktigaste sakfråga som referenspunkter.

Man kan generellt säga att resultaten i figur 5 återspeglar de båda tidigare indikatorerna. Mellan 1982 och 1988 såg bokstavligen inga svarande invandringen som en viktig sakfråga för något av de etablerade partierna. 
Detta förändrades tillfälligt vid valet I99I, när andelen som ansåg att invandringsfrågan var viktig för ett visst specifikt parti ökade till tio procent, men sedan föll tillbaka till tre procent 1994 och noll procent 1998. Sett till hela perioden är det uppenbarligen bara en liten andel av de svarande som uppfattar invandringen som en central sakfråga för de etablerade partierna.

Det ska dock noteras att indikatorn väljaruppfattningar också visar ett viktigt undantag från det allmänna mönstret om att ge låg proritet åt invandringsfrågan: vid valet 2002 uppfattade 56 procent av de svarande invandringsfrågan som viktig för ett visst etablerat parti. Uppenbarligen hände något ovanligt vid den här kampanjen som bör undersökas ytterligare.

Utifrån de resultat som presenterades ovan, kan man dra slutsatsen att alla etablerade partier använt en avvisande sakfrågestrategi gentemot invandringen vid nio av de tolv val som inkluderats $i$ vår analys. I tre färdedelar av de val som inträffade under en period när den etniska heterogeniteten ökade på ett betydande sätt i Sverige, använde alltså de etablerade partierna inte alls invandringsfrågan för att vinna röster. Vid de återstående valen, 199I, 1994 och 2002, visar några av indikatorerna att åtminstone något parti gav högre prioritet åt invandringsfrågan, vilket gör att det blir mindre självklart hur sakfrågestrategin ska klassificeras.

Vid valet 1991 trädde partiet $\mathrm{Ny}$ demokrati in på valarenan genom att driva en anti-etablissemangskampanj, som inkluderade invandringsfientlig politik. Detta ledde till kritiska reaktioner framför allt från Folkpartiet. I figur 5 (med detaljer i tabell 3) kan vi se att väljare för första gången uppfattade att "invandring" var en sakfråga som prioriterades av ett etablerat parti. Vid den tevesända partiledardebatten 1994 verkade invandringsfrågan ha ökat lite i betydelse, vilket man kan se i figur 4 (dess andel av tiden i partiledardebatten ökade från en till fyra procent). ${ }^{6}$

Under valkampanjen 2002 nådde invandringsfrågan sin största betydelse enligt våra indikatorer. Skälet till detta är att Folkpartiet sent under kampanjen introducerade ett kontroversiellt invandringspolitiskt förslag, vilket ledde till reaktioner från de andra partierna.

6. Om Ny demokrati inkluderas i vår kodning av tevedebatten, ökar andelen som ägnas åt invandringsfrågan till tio procent, vilket gör den till den tredje största sakfrågan. 


\section{Figur s. Väljarnas uppfattning av den främsta sakfrågan}

för något politiskt parti under kampanjerna 1982-2006

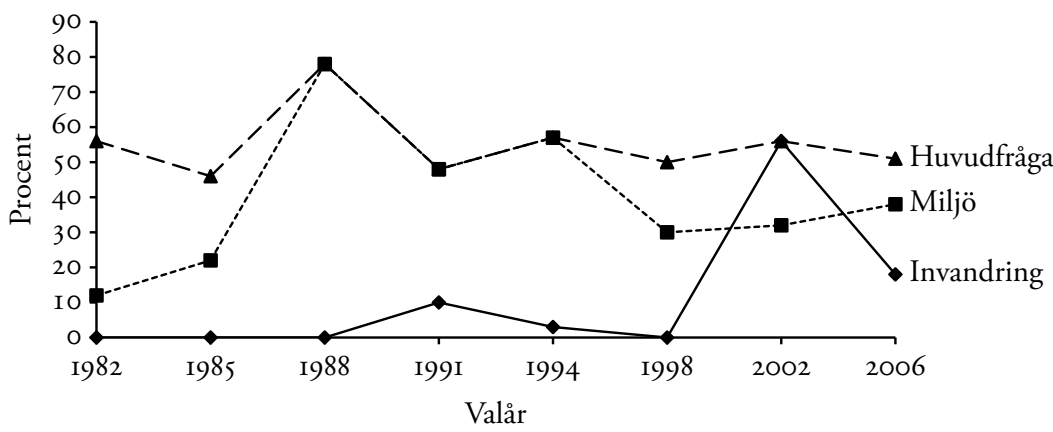

Anmärkning: Andel i procent av väljarna som upplever invandringsfrågor som den viktigaste sakfrågan för något politiskt parti under valkampanjen. Miljön och valets huvudfråga finns med för jämförelsens skull. Från 1988 till 1994 var miljön den främsta sakfrågan, och under 2002 var invandring den främsta sakfrågan.

Källor: Gilljam och Holmberg (1990; 1993; 1995); Holmberg (1984; 2000); Holmberg och Gilljam (1987); Holmberg och Oscarsson (2004); Oscarsson och Holmberg (2008).

För att kategorisera de etablerade partiernas sakfrågestrategier 199I, I994 och 2002 ska vi titta ytterligare på sammanhanget kring dessa val.

\section{Två avgörande perioder: 199I-I994 och 2002-2006}

Vad gäller perioden I99I till I994 är experterna oeniga om vilken strategi som användes av de etablerade partierna. Några hävdar att invandringsfrågan blev viktigare när de etablerade partierna anpassade sig till $\mathrm{Ny}$ demokratis framgångar i valet 199I (Green-Pedersen \& Odmalm 2008, s. 373-374; Hammar 1999, s. 179). Andra hävdar emellertid att frågan inte blev viktig för de etablerade partierna under dessa år (Dahlström 2004, s. 76; Green-Pedersen \& Krogstrup 2008; Rydgren 2002, s. 39).

Vårt empiriska material visar att det tidiga 1990-talet var en kritisk period, men vi vidhåller att de etablerade partierna försökte få bort sakfrågan från den offentliga agendan, snarare än integrera den i sina egna 
plattformar. För det första ska noteras att Ny demokrati under den framgångsrika valkampanjen I99I använde ett anti-etablissemangsbudskap; den invandringsfientliga retoriken var en del av deras kampanj, men det var inget huvudtema. I själva verket visar resultaten som presenteras $\mathrm{i}$ tabell 2 att till och med miljöfrågor var viktigare än invandring i I99I års kampanj. Enbart i Ny demokratis återvalskampanj 1994 blev invandringen huvudfrågan (Rydgren 2002, s. 33-34, observerar samma sak). Eftersom invandringen var ett mycket mer centralt tema I994 än I99I, var Ny demokrati följaktligen känsligare 1994 för den avvisande strategin från de etablerade partiernas sida. ${ }^{7}$

Tabell 2. Ny demokrati och invandringsfrägan (procent)

\begin{tabular}{lcccccc} 
& \multicolumn{2}{c}{ Valmanifest } & \multicolumn{2}{c}{ Tevedebatter } & \multicolumn{2}{c}{$\begin{array}{c}\text { Upplevd betydelse } \\
\text { av utspel }\end{array}$} \\
& I99I & I994 & I99I & I994 & I99I & I994 \\
\hline Invandring & 4 & I0 & 8 & 44 & 9 & 29 \\
Miljö & 5 & 5 & 2 & I & I & I \\
Huvudfråga & I6 & I0 & I7 & 44 & 2 I & 29 \\
\hline
\end{tabular}

Anmärkning: Värdena visar proportionen av utspel för varje fråga vid valkampanjerna I991 och I994.

Källa: Esaiasson och Håkansson (2009) för valmanifest och tevedebatter; Gilljam och Holmberg (1993; 1995) för upplevd betydelse av partiernas utspel.

Som visas i det föregående avsnittet (figur 3-5) hörde inte invandringsfrågan till de viktigare frågorna på den aggregerade nivån 1991. Det samma gäller om vi tittar på de enskilda partierna. I tabell 3 nedan använder vi mer detaljerad information som tydligt visar att inget av de etablerade partierna övergav den avvisande strategin.

7. Det kan verka motsägelsefullt att koda Ny demokrati som ett "invandringsfientligt" parti redan 199I, eftersom invandringsfientlig politik då bara var en del av deras kampanj. Men även om $\mathrm{Ny}$ demokrati inte betonade sin anti-invandringsagenda lika hårt I99I som 1994, var deras politik betydligt striktare än de andra partiernas (se Rydgren 2002; 2004). 


\section{Tabell 3. De etablerade partierna och} invandringsfrigan I99I-2006 (procent)

\begin{tabular}{|c|c|c|c|c|c|c|}
\hline & & I991 & 1994 & 1998 & 2002 & 2006 \\
\hline \multirow[t]{3}{*}{ Vänsterpartiet } & Valmanifest & $\mathrm{I}$ & 2 & 2 & 3 & 3 \\
\hline & Tevedebatter & I & 5 & I & 8 & o \\
\hline & Upplevd betydelse av utspel & o & I & 2 & 3 & $\mathrm{I}$ \\
\hline \multirow[t]{3}{*}{ Socialdemokraterna } & Valmanifest & 3 & I & 2 & 3 & 3 \\
\hline & Tevedebatter & o & I & 2 & 4 & o \\
\hline & Upplevd betydelse av utspel & o & o & o & 5 & $\mathrm{I}$ \\
\hline \multirow[t]{3}{*}{ Miljöpartiet } & Valmanifest & o & o & 6 & 4 & 6 \\
\hline & Tevedebatter & o & 3 & 4 & 15 & o \\
\hline & Upplevd betydelse av utspel & o & o & o & o & $\mathrm{I}$ \\
\hline \multirow[t]{3}{*}{ Centerpartiet } & Valmanifest & 2 & o & I & 5 & 3 \\
\hline & Tevedebatter & o & o & o & 4 & I \\
\hline & Upplevd betydelse av utspel & o & o & o & I & o \\
\hline \multirow[t]{3}{*}{ Folkpartiet } & Valmanifest & I & 3 & 3 & 6 & 6 \\
\hline & Tevedebatter & I & 2 & o & 5 & o \\
\hline & Upplevd betydelse av utspel & IO & 3 & o & 56 & I8 \\
\hline \multirow[t]{3}{*}{ Moderaterna } & Valmanifest & 2 & I & 2 & 2 & 5 \\
\hline & Tevedebatter & o & I 2 & o & 9 & o \\
\hline & Upplevd betydelse av utspel & o & o & o & 2 & o \\
\hline \multirow[t]{3}{*}{ Kristdemokraterna } & Valmanifest & 3 & 2 & o & I & 3 \\
\hline & Tevedebatter & 4 & 6 & o & 9 & o \\
\hline & Upplevd betydelse av utspel & o & 2 & o & $\mathrm{I}$ & $\mathrm{o}$ \\
\hline
\end{tabular}

Källa: Esaiasson och Håkansson (2009) för valmanifest och tevedebatter; Holmberg och Oscarsson (2004), Oscarsson och Holmberg (2008) för upplevd betydelse av partiernas utspel.

Om vi går vidare till 1994 års val tog de etablerade partierna entydigt avstånd från $\mathrm{Ny}$ demokrati, snarare än att anpassa sig till en invandringsfientlig retorik som kunde ha fått ett genomslag inom betydande väljargrupper. I en ovanlig manifestation av enighet i tevedebatten strax innan 
valdagen, gjorde partiledarna i de etablerade partierna klart att invandringen var en ickefråga: "skamlig" var ett av många adjektiv som användes för att karakterisera $\mathrm{Ny}$ demokratis uttryckligen främlingsfientliga politiska förslag (Dahlström 2004, s. 76-78). Vi menar att denna gemensamma aktion är ett särskilt fall av avvisande sakfrågestrategi; väljare som attraherades av Ny demokrati fick veta att deras åsikter var oacceptabla. De etablerade partierna underströk att invandring inte var en viktig sakfråga och mycket få väljare uppfattade också att de etablerade partierna betonade sakfrågan under kampanjen (tabell 3).

Även om det är tydligt vilken sakfrågestrategi som valdes finns det andra detaljer vid 1994 års val som är viktiga för vår förståelse av de olika etablerade partierna. Bale (2003) hävdar som nämnts att etablerade högerpartier har mest att tjäna på att försöka ta över invandringsfrågan. Om man tar hänsyn till det är det oväntat att Moderaterna deltog i den avvisande strategin. Vid en närmare granskning verkar det som om partiledningens strategiska beslut orsakade interna konflikter. Tabell 4 visar den politiska oenigheten mellan riksdagsledamöterna och partiernas väljare om ett restriktivt invandringspolitiskt förslag mellan 1994 och 2006.

Efter 1994 års val hade de flesta moderata riksdagsledamöter ungefär samma åsikt som sina väljare när det gällde att förespråka mer restriktiv invandringspolitik, vilket är unikt i de mätningar som vi presenterar. ${ }^{8} \mathrm{De}$ moderata riksdagsledamöterna förändrade också sedan sin syn 1998, och avlägsnade sig från väljarna. För att ta ett motsatt exempel reagerade de socialdemokratiska ledamöterna, som löpte risk att förlora substantiellt till radikala invandringsfientliga partier, på ett annat sätt på situationen. Medan en majoritet av de socialdemokratiska väljarna fortsatte att vara positiva till förslaget att minska antalet flyktingar, hade övervägande delen av riksdagsledamöterna motsatt åsikt, både 1994 och 1998.

Resultaten antyder att Moderaternas partiledningen inte hade fullt stöd av sin riksdagsgrupp när den avfärdade $\mathrm{Ny}$ demokratis invandringsfientliga politik 1994. Historien kunde ha tagit en annan riktning under 1990-talets första hälft eftersom förmodligen betydande delar av

8. Oturligt nog för den här studiens syfte, men indirekt till stöd för vårt argument att invandringen varit en sakfråga av mindre vikt, var 1994 års valundersökning den första att fråga deltagarna om detta politiska spörsmål. 
Moderaternas riksdagsgrupp var frestade att anta en mer tydlig invandringsfientlig politik. Det visar hur stark den avvisande konsensusen på partiledarnivå var på den tiden. Inte ens när riksdagsledamöternas politiska inställning överensstämde med deras väljares betonade partiet invandringsfrågan.

Tabell 4. Överensstämmelse mellan riksdagsledamöter och deras respektive väljare beträffande ett politiskt förslag om att landet ska acceptera färre flyktingar (procent)

\begin{tabular}{|c|c|c|c|c|c|c|c|c|}
\hline & & 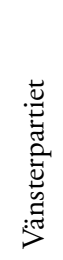 & 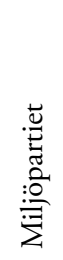 & 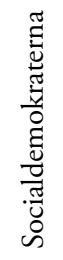 & 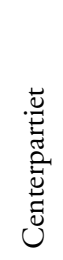 & 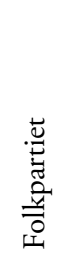 & 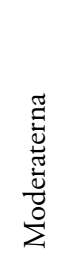 & 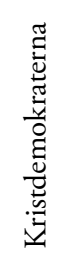 \\
\hline \multirow{3}{*}{ I994 } & Riksdagsledamöter & $\mathrm{o}$ & o & 9 & 6 & o & 74 & $\mathrm{O}$ \\
\hline & Väljare & $5 \mathrm{I}$ & 40 & 75 & 74 & 43 & 78 & 56 \\
\hline & Nivå på överensstämmelsen & $-5 \mathrm{I}$ & -40 & -66 & -68 & -43 & -4 & -56 \\
\hline \multirow{3}{*}{1998} & Riksdagsledamöter & $\mathrm{o}$ & $\mathrm{o}$ & 4 & I7 & $\mathrm{o}$ & 28 & 6 \\
\hline & Väljare & 54 & $4 \mathrm{I}$ & 63 & 58 & 30 & $7 \mathrm{I}$ & 58 \\
\hline & Nivå på överensstämmelsen & -54 & $-4 \mathrm{I}$ & -59 & $-4 \mathrm{I}$ & -30 & -43 & -52 \\
\hline \multirow{3}{*}{2002} & Riksdagsledamöter & $\mathrm{o}$ & o & 7 & 0 & o & 28 & I I \\
\hline & Väljare & 32 & 24 & 60 & 85 & $5 \mathrm{I}$ & $7 \mathrm{I}$ & 53 \\
\hline & Nivå på överensstämmelsen & -32 & -24 & -53 & -65 & $-5 \mathrm{I}$ & -43 & -42 \\
\hline \multirow{3}{*}{2006} & Riksdagsledamöter & o & o & 2 & 4 & 4 & 22 & IO \\
\hline & Väljare & 23 & I7 & 50 & 40 & 39 & 60 & 46 \\
\hline & Nivå på överensstämmelsen & -23 & -17 & -48 & -36 & -35 & -38 & -36 \\
\hline
\end{tabular}

Källa: Holmberg (1996; 2002; 2004; 20I0).

Tabell 3 ovan visade vilken vikt som tillmättes invandringsfrågan enligt våra tre indikatorer (valmanifest, tevedebatter och den upplevda vikten av utspel). Både Moderaterna och Socialdemokraterna fick låga värden på alla tre indikatorerna, vilket visar att alla etablerade partier, oavsett deras politiska positioner, agerade avvisande till och med under 1994 års kampanj. 
Under perioden 2002 till 2006 var ekonomin i ett mycket bättre skick (SCB 2005) och det offentliga stödet för en mer restriktiv invandringspolitik var lägre än under det tidiga I990-talet (Demker 2009, s. 49). Trots det skilde sig 2002 års val mest från det allmänna mönstret av lågt intresse för invandringsfrågan. Huvudorsaken till detta är ett politiskt förslag från Folkpartiet om att introducera ett språktest som krav för medborgarskap (Boréus 2006, s. 134). Förslaget kom in sent i kampanjen, men fick snabbt ökad betydelse på grund av skarp kritik från Socialdemokraterna, Vänsterpartiet och Miljöpartiet (Boréus 2006, s. I33-I34; Holmberg \& Oscarsson 2004, s. I23-I24). Moderaterna hade faktiskt introducerat ett liknande, men mindre uppmärksammat, förslag innan valkampanjen och de uttryckte sig positivt om det under kampanjens sista veckor. Det syns emellertid tydligt i tabell 3 att Moderaterna inte kommunicerade budskapet till väljarna. På det hela taget är det tydligt att Folkpartiet försökte öka invandringsfrågans betydelse under 2002 års valkampanj och att väljarna förstod det.

Som de detaljerade resultaten i tabell 3 visar är det också tydligt att Folkpartiet inte förde fram invandringsfrågan i tevedebatten. I stället var Miljöpartiet och Vänsterpartiet mer aktiva i tevedebatten och de avfärdade ännu en gång Folkpartiets förslag. Reaktionerna från Miljöpartiet och Vänsterpartiet var förmodligen mer en konsekvens av Folkpartiets förslag än en planerad strategisk förändring. De framhävde till exempel inte invandringsfrågan särskilt mycket i sina valmanifest, och väljarna uppfattade inte att invandringsfrågan var viktig för dem (se tabell 3 ).

Om vi använder Meguids (2005; 2008) terminologi, valde Folkpartiet en anpassande strategi, medan Miljöpartiet och Vänsterpartiet valde en konfrontativ strategi. Enligt Meguids teori (2005, s. 350) vinner nischpartiet röster om den konfrontativa strategin är dominant, och detta är just vad som skedde när Sverigedemokraterna fördubblade sitt väljarstöd 2002, om än från en mycket låg nivå (se tabell I). Med hänvisning till utbudsteorin kan det mycket väl vara så att Sverigedemokraternas framgångar dämpades av deras bakgrund i extremhögern. Det stämmer också med Meguids teori att Folkpartiet belönades av väljarna när partiets väljarstöd ökade med 8,7 procentenheter, vilket är en av de största ökningarna för ett parti någonsin i svenska riksdagsval. 
För den här artikelns syfte är det emellertid också viktigt att notera att invandringsfrågan förlorade betydelse vid valet 2006 (se tabell 3). Resultaten visar alltså att de etablerade partierna återgick till sin avvisande strategi. Green-Pedersen och Krogstrup (2008, s. 626) har visat att de borgerliga partierna i Sverige internt var oeniga om invandringsfrågan. Med utgångspunkt från deras analys verkar det rimligt att anta att Folkpartiet övergav sakfrågan för att möjliggöra formerandet av alliansregeringen.

\section{Slutsatser}

I den här artikeln har vi visat att de etablerade partierna i Sverige generellt sett valt en avvisande strategi för att hindra invandringsfientliga partier från att nå framgång. Empiriskt har artikeln för det första visat att det finns en betydande efterfrågan från medborgarna efter mer restriktiv invandringspolitik: under de senaste decennierna har medborgarna uttryckt ett starkt stöd för sådana ståndpunkter; klyftan mellan väljarnas politiska preferenser och riksdagsledamöternas när det gäller invandringsfrågan har varit stor och ihållande; och enligt medborgarna har invandringsfrågan konstant varit ett relativt viktigt problem för landet. Med hjälp av primärdata från kvantitativa analyser av valmanifest och tevesända partiledardebatter har vi för det andra kunnat visa att invandringsfrågan fick relativt liten uppmärksamhet under valkampanjerna mellan I970 och 2006.

Det finns emellertid en viktig avvikelse från det allmänna mönstret. Folkpartiet gjorde ett förvånande utspel under 2002 års valkampanj och föreslog införandet av ett språktest som krav för svenskt medborgarskap, vilket gav invandringsfrågan ökad betydelse. Detta undantag visar att det är möjligt att göra politik av invandringsfrågan även i Sverige och att man åtminstone kan spekulera i om de etablerade partiernas avvisande strategi kan vara på väg att förändras. Enligt vad teorierna om sakfrågestrategier förutsäger (Meguid 2005; se även Arzheimer \& Carter 2006; Arzheimer 2009) bör också noteras att väljarstödet för det största invandringsfientliga partiet, Sverigedemokraterna, har ökat sedan 2002 års val.

Över huvud taget verkar det svenska fallet visa att möjligheten till framgångar för invandringsfientliga partier ökar med vikten som tillmäts 
invandringsfrågan. Den insikten understryker ett möjligt dilemma för etablerade partier som vill hålla nere väljarstödet för invandringsfientliga partier men som samtidigt strävar efter att öka invandringsfrågans betydelse. Den här artikeln bidrar därmed till diskussionen om varför partier ibland avhåller sig från att politisera en sakfråga med väljarpotential. Som visas av det eniga fördömandet av Ny demokrati vid 1994 års val, har enigheten mellan de etablerade partierna hindrat partier som strävat efter att öka invandringsfrågans betydelse. Styrkan hos denna konsensus demonstrerades vid mitten av I990-talet. Trots att många moderata riksdagsmän höll med sina väljare om att invandringen borde vara mer restriktiv, avhöll sig partiledningen från att göra det till en valfråga.

Vad gäller de initiativ som kan tas av individuella partier, verkar det som om etablerade högerpartier har varit frestade att använda en anpassande strategi, medan Vänsterpartiet och Miljöpartiet, som har relativt invandringsvänliga väljare, varit mest frestade att använda en konfrontativ strategi (Bale 2003; 2008). I båda fallen skulle rörelser av det slaget innebära att invandringsfrågan politiseras och att konsensus om den avvisande strategin bryts. Den här dynamiken demonstrerades i 2002 års val, när Folkpartiet skiftade till en tillmötesgående strategi och Vänsterpartiet och Miljöpartiet svarade på ett konfrontativt sätt. Den dramatiska utvecklingen under 2002 års kampanj visar hur snabbt invandring kan blir en viktig valfråga. Därför är den konsensus som finns mellan de etablerade partierna om att avfärda en möjligen röstvinnande sakfråga från kampanjerna bräcklig.

Valet 20IO, när Sverigedemokraterna till slut tog sig in i riksdagen, säger ännu mer om vilka svårigheter som detta innebär. Vi saknar ännu systematisk information om de etablerade partiernas sakfrågestrategier inför det valet, men enligt vår preliminära bedömning höll de sig i stor utsträckning till en avvisande strategi (de etablerade partierna var, emellertid, ofta tvingade av journalister att kommentera implikationerna av det ökade stödet för Sverigedemokraterna i opinionsmätningarna). Trots att vår analys indikerar att den avvisande strategin var framgångsrik under en lång period visar den allra senaste erfarenheten följaktligen gränserna för sakfrågestrategin.

Vad gäller de ytterligare teorier som finns på fältet, finns inget bevis för att den offentliga opinionen blev mer negativ till invandring innan 
valet (se Demker 2009). Eftersom de bakomliggande faktorerna förblev konstanta, verkar det som om Sverigedemokraterna lyckades passera åtminstone några av de begränsningar som hänger samman med deras rötter i den extrema högern (Ignazie 1992; Kitschelt 1995; Carter 2002; Ivarsflaten 2006; jfr Brug, Fennema \& Tillie 2005). Det betyder, om man går ett steg vidare, att vi behöver identifiera under vilka villkor invandringsfientliga partier kan bli mer respektabla i väljarnas ögon och därmed ha större möjligheter att motverka avvisande strategier från de etablerade partiernas sida.

\section{Översättning: Mats Deland och Paul Fuehrer 9}

\section{Referenser}

Anderson, Karen 200I. The Politics of Retrenchment in a Social Democratic Welfare State. Comparative Political Studies 34, 9, s. I063-I091. DOI: http://dx.doi.org/Io.II77/o0I04I400I034009005

Arzheimer, Kai 2009. Contextual Factors and the Extreme Right Vote in Western Europe, 1980-2002. American Journal of Political Science 53, 2, s. 259-275. DOI: http://dx.doi.org/I0.IIII/j.I540-5907.2009.00369.x

Arzheimer, Kai \& Carter, Elisabeth 2006. Political Opportunity Structures and RightWing Extremist Party Success. European Journal of Political Research 45, 3, s. 4I9-443. DoI: http://dx.doi.org/I0.IIII/j.I475-6765.2006.00304.x

Bale, Tim 2003. Cinderella and Her Ugly Sisters: The Mainstream and Extreme Right in Europe's Bipolarising Party Systems. West European Politics 26, 3, s. 67-90. DOI: http://dx.doi.org/Io.IO80/OI402380312331280598

Bale, Tim 2008. Turning Round the Telescope. Centre-Right Parties and Immigration and Integration Policy in Europe. Journal of European Public Policy 15, 3, s. 315-330. DoI: http://dx.doi.org/Io.I080/I350176070184734I

Betz, Hans-Georg 1994. Radical Right-Wing Populism in Western Europe. New York: St. Martins Press.

Boréus, Kristina 2006. Diskrimineringens retorik. Stockholm: Fritzes.

Brothén, Martin \& Holmberg, Sören 2003. Riksdagsenkät 2002. Dokumentation. Göteborg: Statsvetenskapliga institutionen.

Brothén, Martin, Holmberg, Sören \& Eriksson, Mari 2007. Riksdagsenkät 2006. Dokumentation. Göteborg: Statsvetenskapliga institutionen.

Brug, Wouter van der \& Fennema, Meindert 2007. What Causes People to Vote for a Radical-Right Party? A Review of Recent Work. International Journal of Public Opinion Research I9, 4, s. 474-487.

DoI: http://dx.doi.org/IO.IO93/ijpor/edmo3I

9. Översättning av citat: David Lindberg. 
Brug, Wouter van der, Fennema, Meindert \& Tillie, Jean 2005. Why Some Anti-Immigrant Parties Fail and Others Succeed. Comparative Political Studies 38, 5, s. 537-573. DoI: http://dx.doi.org/IO.II77/ooIO4I4004273928

Carter, Elisabeth L. 2002. Proportional Representation and the Fortunes of Right-Wing Extremist Parties. West European Politics 25, 3, s. I25-I46. DoI: http://dx.doi.org/I0.1080/713601617

Carter, Elisabeth L. 2005. The Extreme Right in Western Europe. Success or Failure? Manchester: Manchester University Press.

Coleman, David 2006. Immigration and Ethnic Change in Low-Fertility Countries: A Third Demographic Transition. Population and Development Review 32, 3, s. 40I-446. DoI: http://dx.doi.org/IO.IIII/j.I728-4457.2006.00I31.x

Dahlström, Carl 2004. Nästan välkomna. Invandrarpolitikens retorik och praktik. Göteborg: Statsvetenskapliga institutionen.

Demker, Marie 2009. Generösare attityd till flyktingmottagande i Sverige, i Holmberg, Sören \& Weibull, Lennart (red.) Svensk höst. Göteborg: SOM-institutet.

Esaiasson, Peter 1992. Scandinavia, i Butler, David \& Ranney, Austin (red.) Electioneering. A Comparative Study of Continuity and Change. Oxford: Clarendon Press.

Esaiasson, Peter \& Håkansson, Nicklas 2009. Partiernas opinionspåverkan. Dataset. Göteborg: Statsvetenskapliga institutionen.

Federico, Christopher 2004. When Do Welfare Attitudes Become Racialized? The Paradoxical Effects of Education. American Journal of Political Science 48, 2, s. 374-391. DOI: http://dx.doi.org/IO.IIII/j.0092-5853.2004.00076.x

Fennema, Meindert 1997. Some Conceptual Issues and Problems in the Comparison of Anti-Immigrant Parties in Western Europe. Party Politics 3, 4, s. 473-492. DOI: http://dx.doi.org/I0.1177/I354068897003004002

George, Alexander \& Bennett, Andrew 2004. Case Studies and Theory Development in the Social Sciences. Cambridge: The MIT Press.

Gilens, Martin 1999. Why Americans Hate Welfare. Race, Media, and the Politics of AntiPoverty Policy. Chicago: University of Chicago Press.

Gilljam, Mikael \& Holmberg, Sören I990. Rött, blått, grönt. Stockholm: Bonniers.

Gilljam, Mikael \& Holmberg, Sören 1993. Väljarna inför 90-talet. Stockholm: Norstedts juridik.

Gilljam, Mikael \& Holmberg, Sören 1995. Väljarnas val. Stockholm: Norstedts juridik.

Golder, Matt 2003. Explaining Variation in the Success of Extreme Right Parties in Western Europe. Comparative Political Studies 36, 4, s. 432-466.

DOI: http://dx.doi.org/IO.II77/ooIO4I4003251176

Green-Pedersen, Christoffer \& Krogstrup, Jesper 2008. Immigration as a Political Issue in Denmark and Sweden. European Journal of Political Research 47, 5, s. 610-634. DOI: http://dx.doi.org/IO.IIII/j.I475-6765.2008.00777.x

Green-Pedersen, Christoffer \& Odmalm, Pontus 2008. Going Different Ways? RightWing Parties and the Immigrant Issue in Denmark and Sweden. Journal of European Public Policy 15, 3, s. 367-38I.

DoI: http://dx.doi.org/IO.IO80/1350I76070I847564 
Hammar, Tomas 1985. Introduction, i Hammar, Tomas (red.) European Immigration Policy. A Comparative Study. Cambridge: Cambridge University Press.

Hammar, Tomas I999. Closing the Doors to the Swedish Welfare State, i Brochmann, Grete \& Hammar, Tomas (red.) Mechanisms of Immigration Control. A Comparative Analysis of European Regulation Policies. Oxford: Berg.

Hjerm, Mikael 2007. Do Numbers Really Count? Group Threat Theory Revisited. Journal of Ethnic and Migration Studies 33, 8, s. I253-I275.

DoI: http://dx.doi.org/10.1080/13691830701614056

Holmberg, Sören 1984. Väljare i förändring. Stockholm: Liber förlag.

Holmberg, Sören 1994. Election Studies the Swedish Way. European Journal of Political Research 25, 3, s. 309-322.

DoI: http://dx.doi.org/IO.IIII/j.I475-6765.1994.tboo423.x

Holmberg, Sören 1996. Svensk åsiktsöverensstämmelse, i Rothstein, Bo \& Sälvik, Bo (red.) Vetenskapen om politik. Festskrift till professor emeritus Jörgen Westerstål. Göteborg: Statsvetenskapliga institutionen.

Holmberg, Sören 200o. Välja parti. Stockholm: Norstedts juridik.

Holmberg, Sören 2002. Necessarily Unrepresentative Political Parties, i Fuchs, Dieter, Roller, Edeltraud \& Wessels, Bernhard (red.) Burger und Demokratie in Ost und West. Festschrift für Hans-Dieter Klingemann. Wiesbaden: Westdeutscher Verlag.

Holmberg, Sören 2004. Polarizing Political Parties, i Narud, Hanne Marthe \& Krogstad, Anne (red.) Elections, Parties, and Political Representation. Festschrift for Professor Henry Valen's 8oth Anniversary, specialnummer av Tidsskrift for samfunnsforskning 2.

Holmberg, Sören 20io. Dynamisk representation, i Brothén, Martin \& Holmberg, Sören (red.) Folkets representanter. En bok om riksdagsledamöter och politisk representation $i$ Sverige. Göteborg: Statsvetenskapliga institutionen.

Holmberg, Sören \& Gilljam, Mikael 1987. Väljare och val i Sverige. Stockholm: Bonniers. Holmberg, Sören \& Oscarsson, Henrik 2004. Väljare. Stockholm: Norstedts juridik.

Holmberg, Sören \& Weibull, Lennart 2009. Svensk höst, i Holmberg, Sören \& Weibull, Lennart (red.) Svensk höst. Göteborg: SOM-institutet.

Ignazi, Piero 1992. The Silent Counter-Revolution. Hypotheses on the Emergence of Extreme Right-Wing Parties in Europe. European Journal of Political Research 22, I, s. 3-34.

DOI: http://dx.doi.org/IO.IIII/j.I475-6765.1992.tboo303.x

Integrationsverket 2006. Populism och främlingsmisstro. Sverige i Europa. Norrköping: Integrationsverket.

Ivarsflaten, Elisabeth 2005. The Vulnerable Populist Right Parties: No Economic Realignment Fuelling their Electoral Success. European Journal of Political Research 44, 3, s. 465-492.

DOI: http://dx.doi.org/IO.IIII/j.I475-6765.2005.00235.x

Ivarsflaten, Elisabeth 2006. Reputational Shields. Why Most Anti-Immigrant Parties Failed in Western Europe, 1980-2005. Uppsats presenterad vid American Political Science Associations årsmöte 2006. 
Jackman, Robert \& Volpert, Karin 1996. Conditions Favouring Parties of the Extreme Right in Western Europe. British Journal of Political Science 26, 4, s. 50I-52I. DOI: http://dx.doi.org/IO.IOI7/Sooo7I23400007584

Jennings, Will 2009. The Public Thermostat, Political Responsiveness and Error-Correction: Border Control and Asylum in Britain, 1994-2007. British Journal of Political Science 39, 4, s. 847-870. DoI: http://dx.doi.org/Io.IoI7/Sooo7I2340900074X

King, Gary, Keohane, Robert \& Verba, Sidney 1994. Designing Social Inquiry. Scientific Inference in Qualitative Research. Princeton: Princeton University Press.

Kitschelt, Herbert 1995. The Radical Right in Western Europe. A Comparative Analysis. Ann Arbor: University of Michigan Press.

Knigge, Pia 1998. The Ecological Correlates of Right-Wing Extremism in Western Europe. European Journal of Political Research 34, 2, s. 249-279. Dor: http://dx.doi.org/IO.IIII/I475-6765.00407

Lax, Jeffrey \& Phillips, Justin 2009. Gay Rights in the States: Public Opinion and Policy Responsiveness. American Political Science Review I03, 3, s. 367-386. Dor: http://dx.doi.org/I0.I0I7/Sooo3055409990050

Lieberson, Stanley 1991. Small $N$ s and Big Conclusions: An Examination of the Reasoning in Comparative Studies Based on a Small Number of Cases. Social Forces 70, 2, s. 307-320. DOI: http://dx.doi.org/IO.IO93/sf/70.2.307

Lindvall, Johannes 2004. The Politics of Purpose. Swedish Macroeconomic Policy After the Golden Age. Göteborg: Statsvetenskapliga institutionen.

Lodenius, Anna-Lena \& Larsson, Stieg 1994. Extremhögern. Stockholm: Tiden.

Lubbers, Marcels, Gijsberts, Mérove \& Scheepers, Peer 2002. Extreme Right-Wing Voting in Western Europe. European Journal of Political Research 4I, 3, s. 345-378. Dor: http://dx.doi.org/IO.IIII/I475-6765.00015

Meguid, Bonnie M. 2005. Competition between Unequals: The Role of Mainstream Party Strategy in Niche Party Success. American Political Science Review 99, 3, s. $347-359$. DoI: http://dx.doi.org/I0.I0I7/Soo0305540505170I

Meguid, Bonnie M. 2008. Competition between Unequals. Cambridge: Cambridge University Press.

Mudde, Cas 1996. The War of Words Defining the Extreme Right Party Family. West European Politics 19, 2, s. 225-248. DoI: http://dx.doi.org/Io.Io8o/oI402389608425132

Mudde, Cas 2007. Populist Radical Right Parties in Europe. Cambridge: Cambridge University Press.

Naurin, Elin 2009. Promising Democracy. Göteborgs universitet: Statsvetenskapliga institutionen.

Norris, Pippa 2005. Radical Right. Parties and Electoral Competition. Cambridge: Cambridge University Press.

OECD 2003. Trends in International Migration. Paris. 
Oscarsson, Henrik \& Holmberg, Sören 2008. Regeringsskifte. Stockholm: Norstedts juridik.

Rydgren, Jens 2002. Radical Right Populism in Sweden: Still a Failure, But for How Long? Scandinavian Political Studies 25, I, s. 27-56. DoI: http://dx.doi.org/IO.IIII/I467-9477.00062

Rydgren, Jens 2004. Från skattemissnöje till etnisk nationalism: Is år med den radikala högerpopulismen i Sverige, i Rydgren, Jens \& Widfeldt, Anders (red.) Från Le Pen till Pim Fortuyn. Malmö: Liber.

Rydgren, Jens 2oIo. Den radikala högerns sociologi, i Deland, Mats, Hertzberg, Fredrik \& Hvitfeldt, Thomas (red.) Det vita fältet. Samtida forskning om högerextremism. Uppsala: Historiska institutionen, Uppsala universitet.

SCB 2005. Arbetskraftsundersökningen, mars 2005. Stockholm: Statistiska centralbyrån.

Sides, John \& Citrin, Jack 2007. European Opinion About Immigration: The Role of Identities, Interests and Information. British Journal of Political Science 37, 3, s. 477-504. DOI: http://dx.doi.org/IO.IOI7/Sooo7I23407000257

Swank, Duane \& Betz, Hans-Georg 2003. Globalization, the Welfare State and RightWing Populism in Western Europe. Socio-Economic Review I, 2, s. 215-245. DOI: http://dx.doi.org/Io.I093/soceco/I.2.215

Särlvik, Bo 2002. Party and Electoral System in Sweden, i Grofman, Bernhard \& Lijphart, Arend (red.) The Evolution of Electoral and Party Systems in the Nordic Countries. New York: Agathon Press.

Widfeldt, Anders 2004. The Diversified Approach: Swedish Responses to the Extreme Right, i Eatwell, Roger \& Mudde, Cas (red.) Western Democracies and the New Extreme Right Challenge. London: Routledge.

Zaller, John 1992. The Nature and Origins of Mass Opinion. Cambridge: Cambridge University Press. 


\section{Tomas Peterson, Mikael Stigendal \& Björn Fryklund}

\section{Skånepartiet}

Om folkligt missnöje i Malmö

Efter 66 års styre förlorade socialdemokratin makten i Malmö vid valet 1985. Den avgörande faktorn därbakom var framgången för Carl P. Herslows Skåneparti. I denna bok ger tre sociologer en ingående skildring av detta partis och dess ledares säregna utveckling. Författarna gör också en djuplodande analys av partiets sympatisörer och deras samhällspolitiska världsbild.

Arkiv förlag 1988, mjukband, 289 sidor

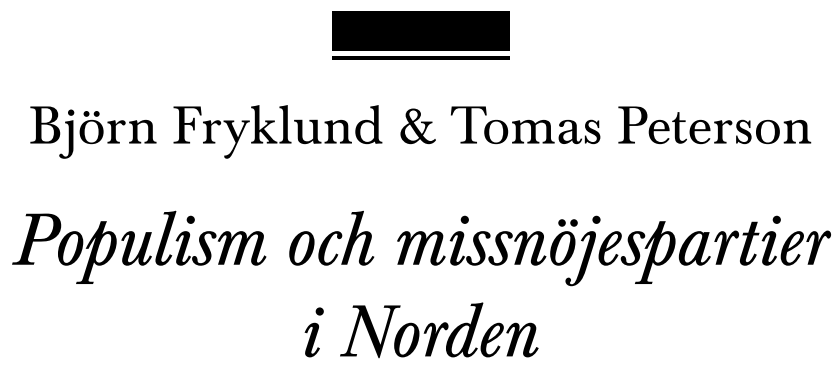

Studier av småborgerlig klassaktivitet

Under de senaste årtiondena har det i de nordiska länderna vuxit fram en ny typ av partier och rörelser, som hämtar sin näring ur ett populistiskt missnöje med det politiska systemet. Mot bakgrund av de fyra nordiska ländernas historia ger författarna en klargörande skildring av dessa rörelsers förutsättningar och betydelse.

Arkiv förlag 1981, mjukband, 470 sidor

»Böckerna går att beställa i bokhandeln och från www.arkiv.nu« 